\title{
Network capitalism and the role of strategy, contracts and performance expectations for Asia-Pacific innovation partnerships
}

\author{
Jochen Schweitzer \\ University of Technology Sydney \\ City Campus Haymarket \\ PO Box 123 Broadway \\ NSW 2007 Australia \\ Tel.: +61295143641 \\ Jochen.Schweitzer@uts.edu.au
}

Research for this paper was aided by support from the Management Discipline Group and the Centre for Management and Organization Studies at the University of Technology Sydney. All errors are our own. 
With the growth of emerging economies in Asia-Pacific over the last three decades collaboration with the aim of innovation between firms within and with partners outside the region have developed substantially. Not always have such partnerships fulfilled their anticipated strategic objectives. The literature suggests that the nature of market arrangements and the role of government within that system play a role, but also innate contracting practices and governance of innovation partnerships are related. Yet, our understanding about the specific relationships between these factors and the emerging partnership innovation culture that facilitates joint business activities in an Asia-Pacific context remains vague. In this conceptual chapter we suggest how characteristics of so called network capitalism in conjunction with the nature of contractual agreements between partners, the alignment of their innovation objectives and the ambiguity inherent in their mutual contributions to the partnership can be interpreted as indicators of joint innovation culture. However, while innovation partnerships generally may result to be bureaucratic, market, clan, or adhocracy, we discuss how in an Asia-Pacific context, innovation partnerships are limited by the extent of codification and diffusion of information and the social embeddedness of economic transactions.

Keywords: Innovation partnerships, contracting, innovation culture, network capitalism

\section{Introduction}

In the last decade the Asia-Pacific region has become ever more central to the long-term strength and prosperity of the global economy. While the most significant development continues to be the rise of China, the entire region is becoming more economically integrated. The past years saw substantial progress on a number of major trade deals that will further strengthen the region's status as the engine of global economic growth. Not only has foreign direct investment (FDI) in the region grown over the years, also outbound foreign direct investment (ODI) by, for example, non-state-owned Chinese companies increased by 35\% in only ten years (MofCom, 2013). According to the Ministry of Commerce of the People's Republic of China, the countries ODI may have exceeded FDI for the first time in 2014 (MofCom, 2015). 
A number of previously regional players have grown to become global players by attracting foreign investment and by forging partnerships within and outside the region, which has helped reinforcing their foothold in the global business community.

Numerous studies have investigated the development strategies of these firms (Bartlett \& Ghoshal, 2000; Ibeh, Johnson, Dimitratos, \& Slow, 2004; Rialp, Rialp, \& Knight, 2005), however little is known about their capacity for further growth based on their capacity to innovate. Yet, innovation is the central strategy for many companies in the region to endure and develop in what are increasingly competitive and dynamic business settings. Co-operation is a vital way for companies to achieve innovation objectives. Regardless of the term 'innovation' being notoriously ambiguous and often lacking a specific definition or measure (Adams, Bessant, \& Phelps, 2006) commercial, noncommercial and government organizations alike view innovation as an essential way of improving managerial efficacy, profitability and overall economic performance. In this chapter, we understand innovation in Schumpeter's (1934) terms, who incorporates five types of activity; new production methods, new sources of supply, the creation of new products, the capitalization of new markets, and organizing business in new ways. The latter especially contains new methods of creating value through collaboration.

Many enablers of innovation strategies have been explored. Examples include strategic vision, culture, governance, and sense of urgency of the organization. Firms that successfully balance exploitative and explorative ways of innovation do so by aligning infrastructure, resources and organizational strategy to create dynamic innovation capabilities (Clegg, Carter, Kornberger, \& Schweitzer, 2011). However, the concept of developing unique competences within the boundaries of one company as an exclusive source of strategic advantage is particularly insufficient in contemporary markets in Asia Pacific. Closed innovation based on self-reliance of R\&D is often too slow and also expensive (Edwards, Logue, \& Schweitzer, 2015). Thus, during the past three decades innovation has gone through evolutionary steps to collaborative innovation and more recently to open-innovation and co-innovation (Lee, Olson, \& Trimi, 2010).

We focus on collaborative innovation, which includes partnerships, strategic alliances, joint ventures, and technology/patent relationships that allow firms combining own competencies with those of other firms (Gudergan \& Schweitzer, 2008). Examples in Asia Pacific include firms such as Nissan, Samsung or the Dongfeng Motor Group and outside the region companies like SEEK, 
Apple, Cisco, HP, Dell, Procter \& Gamble and many others that have successfully collaborated (Tapscott \& Williams, 2008).

Specific alliances are often described very broadly, so that it is nearly impossible to differentiate them from other types of inter-firm relationships and economic transactions like e.g. supplier relationships. As "hybrid" organizational forms they are a way to manage exchanges or relationships that are more complex than a standard market exchange since they involve purposive linkages (Kale, Singh, \& Perlmutter, 2000), exchange, sharing or co-development (Gulati, 1995b) - yet they do not merit full integration (Gulati, 1998; Williamson, 1991; Zenger \& Hesterly, 1997). Hence, we see innovation alliances as a unique form of organization, which in its simplest form can be defined as a group of stakeholders intentionally organized to accomplish an overall, common innovation goal, which is explicit or implicit, carefully considered and established through a strategic planning process.

An example is the recently established Asia Pacific Innovation Center by Johnson \& Johnson in Shanghai with satellites in Singapore, Australia and Japan, thereby extending the existing network of Johnson \& Johnson's strategic innovation initiatives in life sciences hotspots. The centre aims at identifying and developing early-stage opportunities across the company's key strategic focus areas including pharmaceuticals, medical devices and diagnostics and consumer healthcare products. At the heart of this innovation strategy is to collaborate with the best minds in the region to advance new technologies and deliver transformative solutions for the people of China and Asia Pacific at large.

Generally, alliances like the above mentioned have been shown to be effective mechanisms for transferring knowledge (Doz, 1996), spreading risk (Hennart, 1988), learning (Inkpen \& Crossan, 1995; Schweitzer \& Gudergan, 2010) and innovation capability development (Schweitzer, 2014). Research studies have examined a host of factors that relate to how alliances are set up and what their role is in realizing strategic objectives. This growing body of research has also dealt with several aspects of innovation alliances and found, for example, that the ability to successfully set up and manage alliances is affected by the contracting and governance arrangements that are put in place. Similarly, research suggests a positive and significant role of organizational culture or climate on innovation (Ahmed, 1998; Isaksen, Lauer, Ekvall, \& Britz, 2001; Lee, Tan, \& Chiu, 2008) and that innovation within alliances can be achieved by creating a learning culture (Linnarsson \& Werr, 
2004). The specific aspects of alliance contracting, governance and culture are inter-related, but no yet well understood. Such interrelations are particularly important to understand in growing economic environments like the Asia Pacific region, since collaboration for innovation is taking up an increasing part of all innovation activity here (IBM, 2012).

Our focus here is on examining the alliance contractual nature and culture as key aspects for effectively managing innovation partnerships in the Asia Pacific context. We develop a conceptual framework that is embedded in economic perspectives of network capitalism (Boisot \& Child, 1996; Tung \& Worm, 2001), organizational control theory (Ouchi, 1980) and theoretical developments on organizational culture (Cameron \& Quinn, 2011) and alliance contracts and contractual complexity (Ariño \& Reuer, 2006a; Reuer \& Ariño, 2007). Our objective is to add to the academic dialogue about contractual aspects and culture within Asia Pacific innovation alliances.

\section{Theoretical background}

\subsection{Network Capitalism}

Boisot and Child (1996) coined the term 'network capitalism' to describe a distinctive institutional form that had evolved in China due to it's continuing transformation and decentralization of a state controlled bureaucracy. Network capitalism occurred following a combination of limited information codification in China combined with communal property rights and organization of economic transaction. It is largely about the localization of transactions where economic subjects act locally instead of being involved in transactions in a depersonalized market with a potentially unlimited number of participants. In that way, China's path via network capitalism to economic renewal and evidently substantial growth over the last three decades juxtaposes the Western way of market expansion, which is typically based on intensive information codification (Boisot \& Child, 1996; Boisot, Child, \& Redding, 2011).

Yet, the most relevant feature of network capitalism in the context of understanding its role for innovation partnerships is the depth and nature of its social embeddedness and closeness of its actors, which both have deep historical roots in Chinese cultural tradition. The Chinese system of network capitalism had grown under conditions of very considerable uncertainty and until today works through the implicit and fluid dynamic of trust-based relationships, where trust is heavily 
based on familial or community membership that is normally difficult for outsiders to gain. Network capitalism is suited to handling complexity and uncertainty since networks offer greater capacity for generating and transmitting new information. If networks are enabled through trust-based relationships they even offer protection against the possibility of failure - the familiar associate of uncertainty.

Boisot and Child describe closeness in network capitalism by borrowing the concept of 'clans' from Ouchi (1980), expressing how market transactions under network capitalism are embedded in ties of kinship, in other words: friendly relations. Clan structures appreciate the entrepreneurial potential of situations where, for example, government policies provide entry barriers the market. They indeed create a structure for economic activities in informal sectors of the economy and are consequently very flexible and adaptable (Child \& Ihrig, 2013). Not only the thriving economic activities in mainland China but also in Malaysia, Indonesia, Hong Kong, and Singapore are attributed to the fact that economic activities here are largely embedded in Chinese communities and their extended clantype structures (Fukuyama, 1996). The Chinese approach based on clan-like networks also has an advantage in handling and responding to cognitive complexity (Snell \& Tseng, 2002). Hence, with a distinctive Chinese path to growth and modernization suggested, the widespread legitimacy of conventional Western assumptions is truly questioned (Boisot \& Child, 1996).

Further analysis of the difference between modernization in China and Western economies exposed the culture space or C-space (Boisot, 1986, 1987), a conceptual framework that relates the extent to which transactionally relevant information can be diffused, and hence shared, within a target population to how far it has been codified. Without effective codification and given traditional Chinese social organization and embeddedness, decentralization leads not to markets or hierarchies but to clans that permits a much more local and personalized social order of network capitalism. With now extended institutional possibilities it is possible to explain growth and innovation in China. Boisot and Child $(2007$; 2011) further suggest that modern information and communication technologies facilitate network capitalism by lowering the cost of transacting to less codified clanlike structures within populations that are larger and located across great distances.

We note that social embeddedness, information diffusion and information codification are three central features of network capitalism and associate clan-like structures, which are likely to 
determine the development, governance, and management of innovation partnerships within the region and with partners from outside the Chinese and larger Asia-Pacific context.

\subsection{Governance}

Governance of innovation partnerships is about establishing mechanisms that influence and control partners and managers so that their decisions and actions aid common goals. The alliance literature distinguishes relational and formal governance mechanisms (Hoetker \& Mellewigt, 2009) and also defines alliance governance structure by distinguishing non-equity and equity alliances. Formal governance mechanisms are policies, instruments, processes, and practices, which in innovation alliances can involve a performance based pay scheme, use of a board of directors, appointment of local partnership managers, or mutual agreement on formal provisions in a partnership contract. Relational governance relates to social mechanisms that promote open communication and the sharing of information, trust, cooperation and other informal encouragement of a specific work ethic. The alliance partners' choices and combination of governance mechanisms results in a distinct governance form (or structure), which represents the joint organizational context in which the alliance takes place (Ariño \& Reuer, 2006a).

Both, formal and relational governance have been studied widely and are influenced by aspects like co-ordination costs and appropriation concerns (e.g. Gulati \& Singh, 1998; Oxley, 1997); risks; partnership task-scope and transaction-level characteristics (e.g. Oxley, 1999; Oxley \& Sampson, 2004); technological intensity (Osborn \& Baughn, 1990); strategic motivation (Nielsen, 2003); division of labour (Reuer, Zollo, \& Singh, 2002); task complexity and inter-partner diversity (White \& Lui, 2005); trust among partners (e.g. Gulati, 1995a; Krishnan, Martin, \& Noorderhaven, 2006; Lui \& Ngo, 2004; Nooteboom, Berger, \& Noorderhaven, 1997; Zaheer, McEvily, \& Perrone, 1998); and inter-organizational structures (e.g. Gerwin \& Ferris, 2004; Ring \& Van de Ven, 1994; 1992). The management and control of these factors is reflected in the use of contractual provisions between partners (e.g. Reuer \& Ariño, 2003; Reuer, Ariño, \& Mellewigt, 2006; Sampson, 2004), that is, partners use contracts to define mutual rights and obligations by specifying resource allocations, practices of interaction and problem solving, as well as expected outputs (e.g. Argyres, Bercovitz, \& Mayer, 2007; Ariño \& Reuer, 2006a; Lerner \& Merges, 1998; Luo, 2002). These arrangements provide the basis for operating the partnership. In this way, governance mechanisms correspond not only with the structure of the alliance, but also the emerging partnership culture. 


\subsection{Culture}

The organizational culture within innovation partnerships, while related to contracting and governance is also a function of the underlying values and beliefs of the people who are operating it and thereby define in a simple fashion the actor's view of themself and their environment (Schein, 2010). These beliefs and expectations serve as a normative order that influences how people perceive, think, feel and behave (O'Reilly, 1989). As such, culture may directly or indirectly influence alliance governance. While understanding the role of culture remains a difficult task due to its elusive nature (Duncan, 1989), it certainly plays an integral part both as a reflection of and influence on characteristics of innovation partnerships including - for example - the general economic paradigm and by extension the formality and centrality of decision-making, the level to which actions are based on mutual understanding and trust or the degree to which information is codified.

Hence, while governance and culture of innovation partnerships are naturally related, they are also associated with contractual specifications and related complexity. Here, we focus on the emergent organizational culture of the partnership and follow organizational control theory to explain the occurrence of alternative types of partnership cultures. The organizational control perspective (Ouchi, 1980) and later additions (Cameron \& Ettington, 1988; Mintzberg, 1993) suggest that different organizational cultures can be classified in terms of archetypes, namely market, clan, bureaucracy, adhocracy or any hybrid form of these. These types reflect the goal incongruence and performance ambiguity among partners (Cameron \& Quinn, 1999; Ouchi, 1980). Goal incongruence refers to the fact that the goals of partners may not be entirely consistent, describing a state of diverging preferences or a lack of overlapping goals. Performance ambiguity, on the other hand, arises when the measurement of the partners' contributions within the partnership is subject to uncertainty.

Accordingly, antecedent factors to culture including levels of goal incongruence and performance ambiguity result in any one of four archetype cultures being the most efficient to mediate joint transactions: market culture is efficient when performance ambiguity is low and goal incongruence is high, bureaucracy is efficient when both goal incongruence and performance ambiguity are high, clans are efficient when goal incongruence is low and performance ambiguity is high (Ouchi, 1980), and, finally, adhocracies are efficient when goal incongruence and performance ambiguity are low 
(Cameron \& Ettington, 1988; Mintzberg, 1993). The market culture type values productivity and efficiency; information is assumed complete and partners are aware of an explicit competitive price for each task or exchange. With a focus on achievement, this culture emphasizes centralized decision making and more formal coordination and control systems. The partners' commitment to the joint organization's objectives is obtained by self-interest and based on the price mechanism.

Bureaucracies involve close personal surveillance and direction of subordinates by superiors with the information that is necessary for task completion being contained in rules. The cost of administration in bureaucracies is typically high. This culture values stability and control and emphasizes formal coordination, centralized decision-making and vertical communications where team members' roles are defined and enforced through formal rules and regulations.

The clan culture adds a social dimension in assuming that in situations of great uncertainty and complexity, managerial control is established through the group's system of beliefs and perceptions rather than through its behaviour or output. Accordingly, in clan culture it is assumes that individuals are acculturated into a system of controls and meanings. Structurally, there is less emphasis on formal coordination and control systems, and a greater emphasis on participation, decentralized decision-making, horizontal communications and teamwork.

Lastly, adhocracies represent a highly organic and unordered organizational culture. Members within an adhocracy generally perform complex work in small teams with substantial personal communication. Adhocracy is designed to be flexible and adaptable to rapidly changing environments; it emphasizes growth and adaptability. Similar to the clan culture, there is an emphasis on informal coordination, control systems and horizontal communications (Quinn, Hildebrandt, Rogers, \& Thompson, 1991; Zammuto \& Krakower, 1991).

The four cultural orientations are also confirmed by research that examined the relationship between organizational culture and effectiveness (Quinn \& Rohrbaugh, 1981) where it was shown that changes in effectiveness could be explained by an organization's attention inward (toward internal dynamics) versus outward (toward external environment) and its preference for governance to depict flexibility versus control (Goodman, Zammuto, \& Gifford, 2001). 


\subsection{Contracting}

We now consider the role and importance of contracting in innovation partnerships - specifically the contractual complexity of partnership agreements between innovation partners. A generally much observed heterogeneity of partnership agreements is due to variations in contractual complexity, which in turn reflects the often very different relational and situational characteristics of the partnership. Indeed, previous studies have suggested that complexity of agreements is the central concept of contracting (Reuer \& Ariño, 2003). Following this work we understand contractual complexity as a design feature of the partnering firms' agreements that reflects the number and stringency of the provisions that are being employed. Important aspects and antecedents of contractual complexity include asset specificity of the partnership, existence of prior ties among partnering organizations, time boundedness of the agreement, strategic importance of the partnership, and partner search costs (Reuer \& Ariño, 2003). ${ }^{1}$ Although this work captures important aspects of contractual complexity, there are possibly additional factors like types of relational or environmental uncertainty, or the frequency of transactions between partners, or the underlying economic paradigm and organization of economic transaction as well as the degree to which information is codified that can affect the complexity of partnership agreements. Recognizing the early stage of research in understanding antecedents of contractual complexity we focus on the not yet systematically studied link between contractual complexity and partnership culture.

While the different archetypes featured by the organizational control perspective address and explain social, cultural, and relational aspects of the partnership culture, the theory does not explicitly take into account the complexity of contractual provisions between parties; complexity that is heterogeneous across different types of partnerships. Yet, the conceptualization of contractual complexity (Ariño \& Reuer, 2006a) and organizational culture (Ouchi, 1980) share theoretical foundation in transaction cost economics. Both perspectives assume environmental uncertainty, asset specificity, bounded rationality, and behavioural uncertainty to result in transaction costs that mediate the characteristics of the relationship between partnering organizations as well as their joint transactions. Hence, we consider the organizational control perspective as a suitable theoretical basis

\footnotetext{
${ }^{1}$ Asset specificity is the extent of the partners' transaction-specific investments for the partnership; prior ties captures the role of previous partnerships; time boundedness is about the duration to operate the initiative; strategic importance is about the significance that partners give to their collaborative venture; and, finally, partner search concerns the costs that are associated with finding, evaluating, and negotiating with potential partners.
} 
to address the role of contractual complexity in innovation partnerships because both goal incongruence and performance ambiguity share antecedents with contractual complexity.

Goal incongruence, for example, is linked to asset specificity through related levels of decisionmaking uncertainty and trust among alliance members; it relates to partner search costs through associated efforts of strategic goal alignment in the process of finding innovation partners; it is associated with prior ties through the degree of behavioural uncertainty and trust among partners; and it relates to the time boundedness of the partnership through the partners' ability to better predict environmental uncertainties when the duration of the partnership is predetermined.

Performance ambiguity too, is linked to prior ties through existing experience and trust among partners, and it relates to time boundedness through potentially opportunistic partner behaviour in fixed term partnerships. In addition to the common set of antecedents, recent research has shown that variation in partnership governance can also be attributed to contractual complexity (e.g. Reuer \& Ariño, 2007), a concept distinctively different to both goal incongruence and performance ambiguity.

In sum, to better understand the role and potential of innovation partnerships in the Asia-Pacific region, we need to further discuss the theoretical relationships between social embeddedness of actors, diffusion and codification of information (as features of network capitalism) and contractual complexity, performance ambiguity and goal incongruence (as key aspects of partnership governance, contracting and culture). We suppose that the here presented perspectives of network capitalism, organizational control and contracting provide not only a comprehensive explanation for emerging innovation cultures but also a suitable theoretical foundation for our conceptual framework.

\section{Towards a model of Network Capitalism in Asia-Pacific innovation partnerships}

\subsection{Contractual complexity and partnership culture}

First, we argue that the culture of innovation partnerships may differ depending on the complexity of contractual provisions. That is, the various enforcing and coordinating aspects of contractual provisions that guide joint transactions provide control beyond safeguarding partners against unforeseen events or partner opportunism (Ariño \& Reuer, 2006a) since they, together with goal 
incongruence and performance ambiguity, influence the culture of the partnership. In what follows we discuss high, low, and moderate levels of contractual complexity and derive different effects for each of them.

Contractual complexity refers to the stringency of the provisions to control various aspects of the partnership. This can include, for example, enforcement provisions like a detailed account of property rights and knowledge sharing, or informational aspects like measures of performance for each partner organization. Poppo and Zenger (2002) assert that complex contracts are more detailed regarding the specification of promises, obligations, and processes for the resolution of disagreements. Complex contracts include details like roles and responsibilities to be performed or specific procedures for monitoring, consequences of non-compliance, and description of expected outcomes or output.

A bureaucratic culture emerges when the parties to a partnership seek to eliminate the potential for opportunistic behaviour by quantifying and monitoring joint activities and mutual performance. Hence, within bureaucracies, partners assume that the majority of contingencies can be dealt with by policies, standardized procedures, formal division of responsibility, and hierarchical structures (Mintzberg, 1993), which are typically established within the contractual agreement for the partnership.

Low levels of contractual complexity, on the other hand, mean that there are few and lenient provisions agreed upon. Partners may deliberately choose to only agree on a few provisions and not control aspects of the partnership because of high information costs or because contract terms may not be enforceable or are assumed to evolve as the partnership unfolds. Partners may then find it necessary to renegotiate their contracts at some stage, either because they encounter situations in which the contract is silent or where the contract specifies inefficient terms. Yet, while a contractual agreement between collaborating organizations may only encompass a few agreements for a fraction of the partnership's scope, it can still enforce and entirely safeguard partners' interests for the given situation. A complex contract, in contrast, including less enforcement but more informational provisions, might fail to protect partners' interests because of a lack in stringency of the set provisions. Overall, less contractual complexity gives partners more flexibility to experiment with different ways to control and shape the innovation partnership, while at the same time exposing it to more risk involved with uncertain situations. 
Within adhocracies formal and complex contractual agreements are rare because intensive informal interaction, spontaneity, casualness, and interpersonal familiarity act as their coordinating and integrating mechanisms (Jarillo, 1988). Because of these characteristics, adhocracies rely more on relational contracts (e.g. Bryant \& Colledge, 2002; Goldberg, 1976; Heide, 1994; Macaulay, 1963) than on explicit and formal contracts. That is, innovation partners demonstrate flexibility and solidarity while solving problems as they desire continuity in the relationship, so that increased cooperation, dependency, mutual trust, and commitment make it unnecessary to cover all contingencies in complex agreements (Anderson \& Weitz, 1992; Jeffries \& Reed, 2000). Low contractual complexity can therefore support the development of adhocracy cultures for innovation partnerships; it helps foster minimal formalization of procedures, a highly organic structure, and mutual long-term relationships (Achrol, 1997; Daft, 1995). It also allows partners to make decisions without the presence of hierarchical structures and policies (Cameron \& Ettington, 1988; Mintzberg, 1979).

Hence, the interplay of contractual complexity, performance ambiguity, and goal incongruence is associated with different organizational cultures. While high levels of contractual complexity, performance ambiguity, and goal incongruence may lead to bureaucracies, low levels of contractual complexity, performance ambiguity, and goal incongruence may lead to adhocracy governance. We encapsulate the above by advancing the following two hypotheses:

Hypothesis 1: High contractual complexity, high goal incongruence, and high performance ambiguity in innovation partnerships is associated with bureaucracy culture.

Hypothesis 2: Low contractual complexity, low goal incongruence, and low performance ambiguity in innovation partnerships is associated with adhocracy culture.

Moderate contractual complexity represents the partners' intention to balance between too much and too little control through contractual provisions. We associate the clan and market cultures with moderate levels of contractual complexity and suppose that moderate contractual complexity in combination with high performance ambiguity and low goal incongruence results in clan culture, while moderate contractual complexity in combination with low performance ambiguity and high goal incongruence results in market culture. 
This is supported by the characteristics and the information requirements of clan and market cultures. In a partnership that has the attributes of a clan, trust and mutual understanding among the members usually reduces the need for monitoring, both in the pre-contractual and post-contractual phases. Consequently, the formal contracts that bind partners would likely display greater levels of completeness when opportunistic behaviour is a possibility. On these grounds, Williamson and Ouchi distinguish between "hard" and "soft" contracting and argue that soft contracting represents the clan-type culture. Hence, clan culture presumes that the identity of interests between the parties is much closer and formal contracts among parties are incomplete (Williamson, 1975). Further, clan culture is based on traditions where information is implicit; existing but mostly unstated (Ouchi, 1979), it is embedded in established systems of shared values and beliefs, common goals, and mutual understanding that, once adopted, are only moderately explicit and complex. While clan members may share general orientations but not necessarily specific knowledge (Williamson, 1975), they trust each other and trust the fact that know-how always stays within the clan, and that whatever action they take based on whatever knowledge they possess will ultimately be beneficial for all. Accordingly, there is less need to contractually formalize knowledge transfer, restrict knowledge sharing, and safeguard against knowledge spill over effects, since a common vision, shared objectives, and relational bonds among members of the clan predict those risks sufficiently.

The market culture, on the other hand, represents an open structure in which highly autonomous partners establish contractual relationships that are characterized by discrete, often short-term, agreements that aim to facilitate an economically efficient exchange. Partner performance is unambiguous because the conditions and agreements of the collaboration are specific, complete, and monetized. Hence, information requirements within market cultures are explicit, fully accessible, and easy to understand (Ouchi, 1979) so that a market culture is based on simple mechanisms following simple contracts. Moreover, within market culture, exchange objects tend to be nonspecific, that is, the resources, products, services or knowledge that a partner contributes can also be found with other partners (Macneil, 1978; Williamson, 1985). Therefore, highly complex contractual agreements are not necessary since the competitive marketplace and standard contract regulations and corresponding laws provide efficient safeguards to the parties for mediating their transactions (Ring \& Van de Ven, 1992). Besides, in a market culture, partners are equal and free, so that social relations among them are limited since developing them could incur costs or be irrelevant (Williamson, 1985). As a consequence, partners avoid the costs of agreeing on complex contracts 
that can influence and control their transactions. We encapsulate the above in the following two hypotheses.

Hypothesis 3: Moderate contractual complexity, high goal incongruence, and low performance ambiguity in innovation partnerships are associated with market culture.

Hypothesis 4: Moderate contractual complexity, low goal incongruence, and high performance ambiguity in innovation partnerships are associated with clan culture.

\subsection{Innovation partnership culture and network capitalism}

Organizational culture has been repeatedly and consistently shown to play an important role for innovation (Chang \& Lee, 2007; Higgins \& McAllaster, 2002; Lau \& Ngo, 2004; Lloréns Montes, Ruiz Moreno, \& Miguel Molina Fernández, 2004; Martins \& Terblanche, 2003; Mumford, 2000) (Obendhain \& Johnson, 2004; Ruigrok \& Achtenhagen, 1999). While not many studies have examined the role of culture in the Asia-Pacific context, some studies argue from a Western European perspective, that in order to innovate firms have to meet clear requirements in regards to the managerial behaviour within the organization and its management of external relationships (Tylecote, 1996). Others (Siguaw, Simpson, \& Enz, 2006) point out that organizational culture is a facet of operational competency shaped by the innovation orientation of the firm.

Overall, throughout the literature, culture plays a central part in achieving innovation objectives (Ahmed, 1998; Higgins \& McAllaster, 2002; Jamrog, Vickers, \& Bear, 2006; Jassawalla \& Sashittal, 2002; Lau \& Ngo, 2004; Martins \& Terblanche, 2003; Mumford, 2000). It generally influences innovation in two ways: socialization and co-ordination (Tesluk, Farr, \& Klein, 1997). We suggest that innovation partnerships are no different than other organisations in their tendency to develop their own organisational culture. Through socialization, members of the partnership learn whether creative and innovative behaviours are part of what is valued within the partnership. In addition, via co-ordination through activities, policies and procedures the partnership engenders values, which can encourage creative behaviour and reward innovation. As a result the innovative capacity improves. Hence, the culture of innovation partnerships determines the extend to which innovative behaviour among its members is inspired and innovation is accepted as a basic value (Dulaimi \& Hartmann, 2006) so that members of the partnership can foster commitment to it. 
We suggest that the core features of network capitalism including information diffusion, social embeddedness and information codification affect the ability for members of innovation partnerships to develop a culture that fosters innovation. The previous described theoretical relationships between contractual complexity, goal incongruence and performance ambiguity with partnership culture are controlled by the context in which they occur.

Information codification is the selection and compression of data into stable structures (Shannon, 2001); it exists on a continuum and alongside information diffusion. Boisot and Child explain: "If Zen masters trade in the kind of tacit knowledge that is hard to codify and that can only be imparted slowly and face to face to a limited number of disciples, bond traders, by contrast, deal in wellcodified prices that can be diffused worldwide in seconds by electronic means" (Boisot \& Child, 1996, p. 602). Hence, codification and diffusion of information make up the transactional environment and shape the conditions for institutional options of the participating actors. We suggest that low information diffusion under network capitalism confines the effect of goal incongruence but increases the effect of performance ambiguity on partnership culture, while low information codification under network capitalism reduces the effect of contractual complexity on partnership culture.

Similarly, social embeddedness, which is defined as a kind of strong social situatedness or the extent to which modelling the behaviour of an actor requires the inclusion of other actors as individuals rather than as an undifferentiated whole (Edmonds, 1999), affect partnership culture. A high degree of social embeddedness reduces the effect of both goal incongruence and performance ambiguity on partnership culture. With typically uncodified information and limited or restricted information diffusion and high social embeddedness in China, we follow our logic and suggest that clan-like structures are the preferred institutional choice for partnerships in the region.

We encapsulate the above in the following three additional hypotheses.

Hypothesis 5: Information diffusion moderates the effect of goal incongruence and performance ambiguity on partnership culture of innovation partnerships.

Hypothesis 6: Social embeddedness moderates the effect of goal incongruence and performance ambiguity on partnership culture of innovation partnerships. 
Hypothesis 7: Information codification moderates the effect of contractual complexity on partnership culture of innovation partnerships.

Figure 1 depicts the proposed relationships.

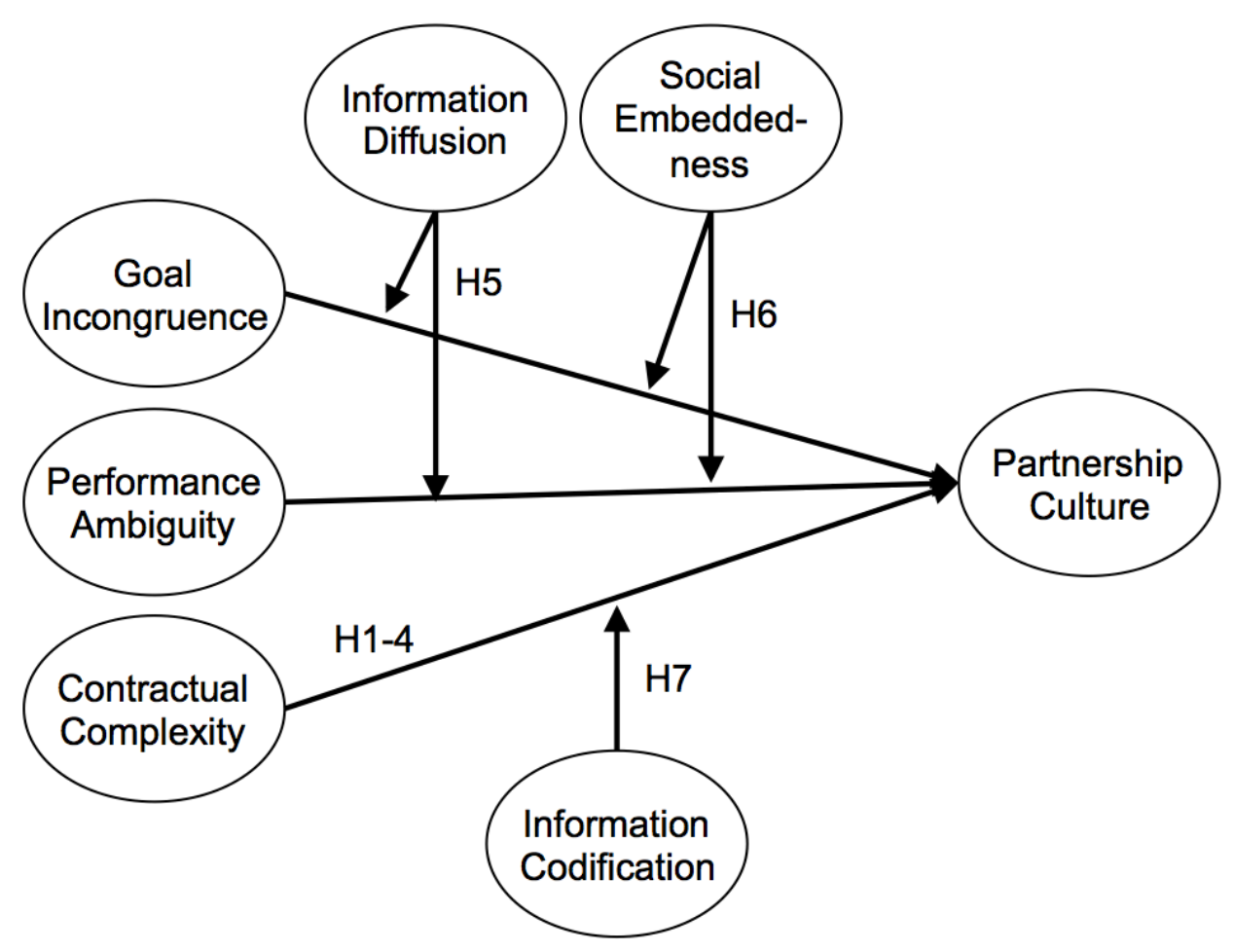

Overall, network capitalism favours clan culture that stresses flexibility while focusing on internal organization. Characteristics of clan-type innovation partnerships include teamwork, involvement and the partnering organisation's commitment to members of the partnership. Autonomy and freedom based on social embeddedness, low information codification and diffusion encourage creativity, which is the key for developing innovations. This contrasts the existence of rules and regulations and excessive authority or poor participation of members that will limit the capacity of partnership members to assume the risks of innovation (Child, 1973).

\section{Conclusion}

The present chapter is an initial theoretical investigation of the relationships between network capitalism and the contractual complexity of partnership agreements, the goal incongruence and 
performance ambiguity among innovation partners as well as the implications of these factors for the organisational culture of innovation partnerships. Our aim was to clarify the intricacies of certain facets of the Asia-Pacific region in conjunction with current thinking about how partnerships achieve the necessary conditions for achieving innovation outcomes. We discussed the roles of information codification and diffusion and social embeddedness as important elements of network capitalism and their relationship with contractual complexity, goal incongruence and performance ambiguity as important factors determining the organisational cultures present in contemporary innovation partnerships.

Bureaucracy, market, clan, and adhocracy cultures are different alternatives to safeguard opportunistic threats in innovation partnerships based on their associated levels of goal incongruence, performance ambiguity, and contractual complexity. Yet - in the Asia-Pacific context such choices might be limited given the effect of network capitalism. The primary objective of our framework is to discuss and integrate the related literature, thereby framing network capitalism as an important factor for the development of innovation partnerships in the region.

Our framework contributes to the study of innovation, contracting, and governance in various ways. While previous research regarding contractual complexity in innovation partnerships has focused on the role and importance of contributory influences (e.g. Ariño, Ragozzino, \& Reuer, 2006; Ariño \& Reuer, 2006a; Reuer \& Ariño, 2002, 2007; Reuer et al., 2006), our conceptualization further expands this research by discussing the implication of contractual complexity for partnership innovation culture. In the same way, we begin to fill an important gap in the partnership culture literature by examining a specific aspect, that is, network capitalism, and its implications for emerging partnership cultures and structures in Asia-Pacific.

From a managerial perspective our conceptual framework suggest how important it is for innovation partners to better understand what the roles of strategy, contracts and performance expectations are particularly when aiming for specific innovation outcomes with partners in Asia-Pacific. For example, the firm's ability to negotiate partnership contracts under of network capitalism is greatly influenced by a range of factors which, when explicit and better understood, can help the partners avoid futile complex agreements or, on the other hand, include critical agreements to safeguard against the unwanted actions of partners and innovation team members. 
A limitation of our framework and this study is that it rests on restricted theoretical assumptions. Even though we focus on the perspectives of network capitalism and organizational control theory, there might be other aspects of partnership and alliance management that would be important to consider. For example, Ring and Van de Vens' (1994) process perspective of alliance contracting implies an influence of a psychological contract on the behavioural uncertainty that the contracting parties face once they are partners. Another theoretical perspective that we have not considered here and which has in general not been considered much in the field of partnership management and governance is the organizational behaviour perspective (Ariño \& Reuer, 2006b).

Future research could, for example, include further factors that determine the environment of economic transactions in Asia-Pacific, or take a specific look at the implications of the relationships proposed in this chapter and examine how they relate to other innovation management and collaboration phenomena. This may include various types of behavioural dynamics at the individual or group level, process dimensions of collaboration, and the organizational and managerial context of partnership formation and management including managerial capabilities, leadership behaviour, and the functioning of teams within and across organisations. Hence, expanding on the model presented here offers a plethora of additional research opportunities. 


\section{References}

Achrol, R. S. 1997. Changes in the Theory of Interoganisational Relations in Marketing: Toward a Network Paradigm. Journal of the Academy of Marketing Science, 25(1): 56-71.

Adams, R., Bessant, J., \& Phelps, R. 2006. Innovation management measurement: A review. International Journal of Management Reviews, 8(1): 21-47.

Ahmed, P. K. 1998. Culture and climate for innovation. European journal of innovation management, 1(1): 30-43.

Anderson, E., \& Weitz, B. A. 1992. The Use of Pledges to Build and Sustain Commitment in Distribution Channels. Journal of Marketing Research, 29: 18-34.

Argyres, N. S., Bercovitz, J., \& Mayer, K. J. 2007. Complementarity and Evolution of Contractual Provisions: An Empirical Study of IT Services Contracts. Organization Science, 18(1): 3-19.

Ariño, A., Ragozzino, R., \& Reuer, J. J. 2006. Contractual Renegotiations in Entrepreneurial Alliances. In A. Ariño, \& J. J. Reuer (Eds.), Strategic Alliances: Governance and Contracts. London, UK: Palgrave.

Ariño, A., \& Reuer, J. J. 2006a. Alliance Contractual Design. In O. Shenkar, \& J. J. Reuer (Eds.), Handbook of strategic alliances: 149-167. Thousand Oaks: Sage Publications.

Ariño, A., \& Reuer, J. J. 2006b. Introduction: Governance and Contracts in Strategic Alliances. In A. Ariño, \& J. J. Reuer (Eds.), Strategic Alliances: Governance and Contracts. London, UK: Palgrave.

Bartlett, C., \& Ghoshal, S. 2000. GOING GLOBAL. Harvard Business Review, 78(2): 132-141.

Boisot, M., \& Child, J. 1996. From fiefs to clans and network capitalism: Explaining China's emerging economic order. Administrative Science Quarterly, 41(4): 600-628.

Boisot, M., \& Child, J. 2007. 7. China and the new economy: a case of convergence? The Digital Business Ecosystem: 127.

Boisot, M., Child, J., \& Redding, G. 2011. Working the system: Toward a theory of cultural and institutional competence. International Studies of Management \& Organization, 41(1): 6295.

Bryant, A., \& Colledge, B. 2002. Trust in Electronic Commerce Business Relationships. Journal of Electronic Commerce Research, 3(2): 32-39.

Cameron, K. S., \& Ettington, D. R. 1988. Conceptual foundations of organizational culture. In J. C. Smart (Ed.), Higher education: handbook of theory and research, Vol. 4: 356-396. New York: Agathon Press. 
Cameron, K. S., \& Quinn, R. E. 1999. Diagnosing and changing organizational culture. Upper Saddle River, NJ: Prentice-Hall.

Cameron, K. S., \& Quinn, R. E. 2011. Diagnosing and changing organizational culture: Based on the competing values framework: John Wiley \& Sons.

Chang, S., \& Lee, M. 2007. The effects of organizational culture and knowledge management mechanisms on organizational innovation: An empirical study in Taiwan. The Business Review, 7(1): 295-301.

Child, J. 1973. Predicting and understanding organization structure. Administrative Science Quarterly: 168-185.

Child, J., \& Ihrig, M. 2013. Knowledge, Organization, and Management: Building on the Work of Max Boisot: Oxford University Press.

Clegg, S., Carter, C., Kornberger, M., \& Schweitzer, J. 2011. Strategy: Theory and practice: Sage Publications, Incorporated.

Daft, R. L. 1995. Organization theory and design (5th ed.). Minneapolis, St. Paul: West Publishing Company.

Doz, Y. L. 1996. The Evolution of Cooperation in Strategic Alliances: Initial Conditions or Learning. Strategic Management Journal, 17: 55-83.

Dulaimi, M., \& Hartmann, A. 2006. The role of organizational culture in motivating innovative behaviour in construction firms. Construction Innovation, 6(3): 159-172.

Duncan, W. J. 1989. Organizational culture:"Getting a fix” on an elusive concept. The Academy of Management Executive, 3(3): 229-236.

Edmonds, B. 1999. Capturing Social Embeddedness: a constructivist approach. Adaptive Behavior, 7(3-4): 323-347.

Edwards, M., Logue, D., \& Schweitzer, J. 2015. Towards an understanding of open innovation in services: beyond the firm and towards relational co-creation, The Handbook of Service Innovation: 75-90: Springer London.

Fukuyama, F. 1996. Trust: The social virtues and the creation of prosperity: Free press New York.

Gerwin, D., \& Ferris, J. S. 2004. Organizing New Product Development Projects in Strategic Alliances. Organization Science, 15(1): 22-38.

Goldberg, V. 1976. Towards an Expanded Economic Theory of Contract. Journal of Economic Issues, 10: 45-61.

Gudergan, S. P., \& Schweitzer, J. 2008. Alliances. In S. Clegg, \& J. R. Bailey (Eds.), International encyclopedia of organization studies: 51-55. Thousand Oaks, CA: Sage Publications. 
Gulati, R. 1995a. Does familiarity breed trust? The implications of repeated ties for contractual choice in alliances. Academy of Management Journal, 38(1): 85-112.

Gulati, R. 1995b. Social structure and alliance formation pattern: A longitudinal analysis. Administrative Science Quarterly, 40: 619-642.

Gulati, R. 1998. Alliances and Networks. Strategic Management Journal, 19: 293-317.

Gulati, R., \& Singh, H. 1998. The architecture of cooperation: Managing coordination costs and appropriation concerns in strategic alliances. Administrative Science Quarterly, 43(4): 781815.

Heide, J. B. 1994. Interorganisational Governance in Marketing Channels. Journal of Marketing, 58: 71-85.

Hennart, J.-F. 1988. A transaction cost theory of equity joint ventures. Strategic Management Journal, 9(4): 361-374.

Higgins, J. M., \& McAllaster, C. 2002. Want innovation? Then use cultural artifacts that support it. Organizational Dynamics, 31(1): 74-84.

Hoetker, G., \& Mellewigt, T. 2009. Choice and performance of governance mechanisms: matching alliance governance to asset type. Strategic Management Journal, 9999(9999): n/a.

Ibeh, K., Johnson, J. E., Dimitratos, P., \& Slow, J. 2004. Micromultinationals: Some preliminary evidence on an emergent 'star' of the international entrepreneurship field. Journal of International Entrepreneurship, 2(4): 289-303.

IBM. 2012. Leading Through Connections: The global CEO study. Somers, NY: IBM Institute for Business Value.

Inkpen, A. C., \& Crossan, M. M. 1995. Believing Is Seeing: Joint Ventures and Organization Learning*. Journal of Management Studies, 32(5): 595-618.

Isaksen, S. G., Lauer, K. J., Ekvall, G., \& Britz, A. 2001. Perceptions of the best and worst climates for creativity: Preliminary validation evidence for the situational outlook. Creativity Research Journal, 13: 171-184.

Jamrog, J., Vickers, M., \& Bear, D. 2006. Building and sustaining a culture that supports innovation. People and Strategy, 29(3): 9.

Jarillo, J. C. 1988. On Strategic Networks. Strategic Management Journal, 9(1): 31-41.

Jassawalla, A. R., \& Sashittal, H. C. 2002. Cultures that support product-innovation processes. The Academy of Management Executive, 16(3): 42-54.

Jeffries, F. L., \& Reed, R. 2000. Trust and adaptation in relational contracting. Academy of Management Review, 25(4): 873-883. 
Kale, P., Singh, H., \& Perlmutter, H. 2000. Learning and protection of proprietary assets in strategic alliances: building relational capital. Strategic Management Journal, 21(3): 217-237.

Krishnan, R., Martin, X., \& Noorderhaven, N. G. 2006. When does trust matter to alliance performance? Academy of Management Journal, 49(5): 894-917.

Lau, C. M., \& Ngo, H. Y. 2004. The HR system, organizational culture, and product innovation. International business review, 13(6): 685-703.

Lee, C.-K., Tan, B., \& Chiu, J.-Z. 2008. The impact of organisational culture and learning on innovation performance. International Journal of Innovation and Learning, 5(4): 413-428.

Lee, S. M., Olson, D. L., \& Trimi, S. 2010. Strategic innovation in the convergence era. International Journal of Management and Enterprise Development, 9(1): 1-12.

Lerner, J., \& Merges, R. P. 1998. The control of technology alliances: An empirical analysis of the biotechnology industry. Journal of Industrial Economics, 46: 125-156.

Linnarsson, H., \& Werr, A. 2004. Overcoming the innovation-alliance paradox: a case study of an explorative alliance. European Journal of Innovation Management, 7(1): 45-55.

Lloréns Montes, F. J., Ruiz Moreno, A., \& Miguel Molina Fernández, L. 2004. Assessing the organizational climate and contractual relationship for perceptions of support for innovation. International Journal of manpower, 25(2): 167-180.

Lui, S. S., \& Ngo, H.-Y. 2004. The Role of Trust and Contractual Safeguards on Cooperation in Non-equity Alliances. Journal of Management, 30(4): 471-485.

Luo, Y. 2002. Contract, cooperation, and performance in international joint ventures. Strategic Management Journal, 23(10): 903-919.

Macaulay, S. 1963. Non contractual relations in business: A preliminary study. The American Economic Review, 28 (1): 55-69.

Macneil, I. R. 1978. Contracts: Adjustment of Long-term Economic Relations Under Classical, Neoclassical and Relational Contract Law. Northwestern University Law Review, 72: 854905.

Martins, E., \& Terblanche, F. 2003. Building organisational culture that stimulates creativity and innovation. European journal of innovation management, 6(1): 64-74.

Mintzberg, H. 1979. The structuring of organizations. Englewood Cliffs, NJ: Prentice-Hall.

Mintzberg, H. 1993. Structure in fives. Designing effective organizations. Englewood Cliffs, NJ: Prentice-Hall.

MofCom. 2013. Import and Export Statistics: People's Republic of China Ministry of Commerce. MofCom. 2015. Import and Export Indicators: People’s Republic of China Ministry of Commerce. 
Mumford, M. D. 2000. Managing creative people: Strategies and tactics for innovation. Human resource management review, 10(3): 313-351.

Nielsen, B. B. 2003. An Empirical Investigation of the Drivers of International Strategic Alliance Formation. European Management Journal, 21(3): 301-322.

Nooteboom, B., Berger, H., \& Noorderhaven, N. G. 1997. Effects of trust and governance on relational risk. Academy of Management Journal, 40(2): 308-339.

O'Reilly, C. 1989. Corporations, Culture, and Commitment: Motivation and Social Control in Organizations. California Management Review, 31(4): 9-25.

Obendhain, A. M., \& Johnson, W. C. 2004. Product and process innovation in service organizations: The influence of organizational culture in higher education institutions. Journal of Applied Management and Entrepreneurship, 9(3): 91.

Osborn, R. N., \& Baughn, C. C. 1990. Forms of Interorganizational Governance for Multinational Alliances. Academy of Management Journal, 33(3): 503-519.

Ouchi, W. G. 1979. A conceptual framework for the design of organizational control mechanisms. Management Science, 25(9): 833-848.

Ouchi, W. G. 1980. Markets, Bureaucracies, and Clans. Administrative Science Quarterly, 25(1): 129-141.

Oxley, J. E. 1997. Appropriability hazards and governance in strategic alliances: A transaction cost approach. Journal of Law, Economics and Organization, 13(2): 387-409.

Oxley, J. E. 1999. Institutional environment and the mechanisms of governance: the impact of intellectual property protection on the structure of inter-firm alliances. Journal of Economic Behavior and Organization, 38(3): 283-309.

Oxley, J. E., \& Sampson, T. C. 2004. The Scope and Governance of International R\&D Alliances. Strategic Management Journal, 25(8-9): 723-749.

Poppo, L., \& Zenger, T. 2002. Do formal contracts and relational governance function as substitutes or complements? Strategic Management Journal, 23(8): 707-725.

Quinn, R. E., Hildebrandt, H. W., Rogers, P. S., \& Thompson, M. P. 1991. A competing values framework for analyzing presentational communication in management contexts. Journal of Business Communication, 28(3): 213-232.

Quinn, R. E., \& Rohrbaugh, J. 1981. A Competing Values Approach to Organizational Effectiveness. Public Productivity Review, 5(2): 122-140.

Reuer, J. J., \& Ariño, A. 2002. Contractual Renegotiations in Strategic Alliances. Journal of Management, 28(1): 47-68. 
Reuer, J. J., \& Ariño, A. 2003. Strategic alliances as contractual forms. Paper presented at the Academy of Management (AoM), Seatle, USA.

Reuer, J. J., \& Ariño, A. 2007. Strategic alliance contracts: dimensions and determinants of contractual complexity. Strategic Management Journal, 28(3): 313-330.

Reuer, J. J., Ariño, A., \& Mellewigt, T. 2006. Entrepreneurial Alliances as Contractual Forms. Journal of Business Venturing, 21(3): 306-325.

Reuer, J. J., Zollo, M., \& Singh, H. 2002. Post-formation dynamics in strategic alliances. Strategic Management Journal, 23(2): 135-151.

Rialp, A., Rialp, J., \& Knight, G. A. 2005. The phenomenon of early internationalizing firms: what do we know after a decade (1993-2003) of scientific inquiry? International Business Review, 14(2): 147-166.

Ring, P., \& Van de Ven, A. 1994. Developmental Processes of Cooperative Interorganizational Relationships. Academy of Management Review, 19(1): 90-118.

Ring, P., \& Van de Ven, A. H. 1992. Structuring Cooperative Relationships Between Organizations. Strategic Management Journal, 13(7): 483-498.

Ruigrok, W., \& Achtenhagen, L. 1999. Organizational culture and the transformation towards new forms of organizing. European Journal of work and organizational psychology, 8(4): 521536.

Sampson, R. C. 2004. The Cost of Misaligned Governance in R\&D Alliances. Journal of Law Economics \& Organization, 20(2): 484-526.

Schein, E. H. 2010. Organizational culture and leadership: John Wiley \& Sons.

Schumpeter, J. A. 1934. The theory of economic development: an enquiry into profits, capital, credit, interest and the business cycle. Cambridge, Mass.: Harvard University Press.

Schweitzer, J. 2014. Leadership and innovation capability development in strategic alliances. Leadership \& Organization Development Journal, 35(5): 442-469.

Schweitzer, J., \& Gudergan, S. 2010. Leadership behaviours as ongoing negotiations and their effects on knowledge and innovation capabilities in alliances. International Journal of Knowledge Management Studies, 4(2): 176-197.

Shannon, C. E. 2001. A mathematical theory of communication. ACM SIGMOBILE Mobile Computing and Communications Review, 5(1): 3-55.

Siguaw, J. A., Simpson, P. M., \& Enz, C. A. 2006. Conceptualizing innovation orientation: a framework for study and integration of innovation research*. Journal of Product Innovation Management, 23(6): 556-574. 
Snell, R., \& Tseng, C. S. 2002. Moral atmosphere and moral influence under China's network capitalism. Organization Studies, 23(3): 449-478.

Tapscott, D., \& Williams, A. D. 2008. Wikinomics: How mass collaboration changes everything: Penguin. com.

Tesluk, P. E., Farr, J. L., \& Klein, S. R. 1997. Influences of organizational culture and climate on individual creativity. The Journal of Creative Behavior, 31(1): 27-41.

Tung, R. L., \& Worm, V. 2001. Network capitalism: the role of human resources in penetrating the China market. International Journal of Human Resource Management, 12(4): 517-534.

Tylecote, A. 1996. Cultural differences affecting technological innovation in Western Europe. European Journal of Work and Organizational Psychology, 5(1): 137-147.

White, S., \& Lui, S.-Y. S. 2005. Distinguishing costs of cooperation and control in alliances. Strategic Management Journal, 26(10): 913-932.

Williamson, O. E. 1975. Market and Hierarchies: Analysis and Antitrust Implications. New York: Free Press.

Williamson, O. E. 1985. The Economic Institution of Capitalism. New York: Free Press.

Williamson, O. E. 1991. Comparative economic organization: The analysis of discrete structural alternatives. Administrative science quarterly: 269-296.

Zaheer, A., McEvily, B., \& Perrone, V. 1998. Does Trust Matter? Exploring the Effects of Interorganizational and Interpersonal Trust on Performance. Organization Science, 9(2): 141-159.

Zammuto, R. F., \& Krakower, J. Y. 1991. Quantitative and qualitative studies of organizational culture. Greenwich, CT: JAI Press Inc.

Zenger, T. R., \& Hesterly, W. S. 1997. The disaggregation of corporations: Selective intervention, high-powered incentives, and molecular units. Organization Science, 8(3): 209-222. 